\title{
KERAGAAN REPRODUKSI IKAN PATIN NASUTUS (Pangasius nasutus Bleeker, 1863) SEBAGAI KANDIDAT IKAN BUDIDAYA
}

\author{
Evi Tahapari, Bambang Iswanto, dan Sularto \\ Loka Riset Pemuliaan dan Teknologi Budidaya Perikanan Air Tawar \\ Jl. Raya 2 Sukamandi, Subang-Jawa Barat 41256 \\ E-mail:evitahapari@yahoo.co.id
}

(Naskah diterima: 22 Juni 2010; Disetujui publikasi: 14 April 2011)

\begin{abstract}
ABSTRAK
Patin nasutus merupakan salah satu spesies patin Indonesia yang potensial untuk dikembangkan sebagai komoditas baru perikanan budidaya. Upaya pengembangan patin nasutus memerlukan informasi-informasi biologi-reproduksi berkaitan dengan kapasitas produksi massalnya. Penelitian ini bertujuan untuk mengetahui keragaan reproduksi patin nasutus. Hasil pengamatan perkembangan gonad menunjukkan bahwa oosit intraovarian patin nasutus dapat dibagi dalam lima tahap, yakni tahap 1 (kromatin nukleolar dan perinukleolar) dengan diameter oosit kurang dari 0,125 mm, tahap 2 (vesikula kuning telur dan alveoli korteks) dengan diameter oosit 0,125-0,500 mm, tahap 3 (granula kuning telur) dengan diameter oosit 0,700-1,850 mm, tahap 4 (migrasi nukleus dan hidrasi) dengan diameter oosit 1,250-1,900 mm dan tahap 5 (atresis) dengan diameter oosit 0,300-1,700 mm. Perkembangan oosit patin nasutus bersifat sinkronis grup, ditandai dengan adanya dominasi dua kelompok oosit intraovarian pada ikan dengan tingkat kematangan yang tertua, yakni kelompok oosit tertua (oosit tahap 3) yang akan segera dikeluarkan pada saat pemijahan dan kelompok oosit stok yang belum berkuning telur dan berukuran kecil (oosit tahap 1) yang merupakan telur cadangan untuk proses pemijahan berikutnya. Oosit tahap 3 merupakan tahap perkembangan oosit tertua yang dapat terjadi secara sempurna dan responsif terhadap induksi stimulasi hormonal. Tipe perkembangan testis patin nasutus bersifat asinkronis, ditandai dengan keberadaan berbagai tahap perkembangan sel-sel gamet jantan. Fekunditas relatif patin nasutus berkisar 26-67 butir telur per gram bobot induk, lebih tinggi daripada patin jambal, tetapi lebih rendah daripada patin siam. Derajat penetasan patin nasutus berkisar 44,16-79,05\% dengan lama inkubasi 22-25 jam pada suhu inkubasi $29-30^{\circ} \mathrm{C}$. Ukuran panjang total larva yang baru menetas berkisar 4,700-5,200 $\mathrm{mm}$.
\end{abstract}

KATA KUNCl: reproduksi, oosit, fekunditas relatif, Pangasius nasutus

ABSTRACT: Reproductive performances of patin nasutus (Pangasius nasutus Bleeker, 1863) as a potential candidate for fish culture. By: Evi Tahapari, Bambang Iswanto, and Sularto

Pangasius nasutus is one of Indonesian pangasiid catfish species and has the potential as a new candidate for fish culture. In developing the culture potential of $\boldsymbol{P}$. nasutus, its reproductive biology information in relation to its reproductive capacity has to be determined. The aim of the present study was to investigate the characteristics of reproductive/gonadal development. The result of gonadal development observation shows that intraovarian oocytes of $\boldsymbol{P}$. nasutus comprises of five stages, i.e. stage 1 (chromatin nucleolar and perinucleolar) with oocytes diameter less than $0.125 \mathrm{~mm}$, stage 2 (yolk vesicles and cortical alveolar) with 
oocytes diameter of 0.125-0.500 mm, stage 3 (yolk granules) with oocytes diameter of 0.700-1.850 mm, stage 4 (migratory nucleus and hydrated oocytes) with oocytes diameter of 1.250-1.900 $\mathrm{mm}$ and stage 5 (atretic oocytes) with oocytes diameter of $0.300-1.700 \mathrm{~mm}$. The development of the oocytes was categorized as group synchronism, marked by the dominance of two oocyte groups within the mature ovaries, i.e. the most advanced oocytes (stage 3) which will be released during the spawning and the immature ones which is still unyolked (stage 1) as oocytes stock for the next spawning. Stage 3 was the most normally advanced oocytes stage which could develope perfectly and responsive to hormonal inducement. Rythm of the testicular development was asynchronism, characterized by the presence of male germ cells at various stages of development. The relative fecundity varied between 26-67 eggs per gram body weight of fish, higher than that of P. djambal, but lower than that of P. hypophthalmus. The hatching rates varied between $44.16-79.05 \%$ with the incubation period of $22-25$ hours at $29-30^{\circ} \mathrm{C}$. Total length of the newly hatched larvae was 4.700-5.200 $\mathrm{um}$.

\section{KEYWORDS: reproductive, oocytes, relative fecundity, Pangasius nasutus}

\section{PENDAHULUAN}

Patin merupakan salah satu komoditas perikanan budidaya yang diunggulkan oleh Kementerian Kelautan dan Perikanan, terutama sebagai komoditas ekspor patin daging putih (Nurdjana, 2006). Indonesia memiliki 14 spesies dari 28 spesies patin yang telah diidentifikasi (Gustiano, 2009), dan diantara spesies-spesies patin tersebut terdapat spesies-spesies yang potensial untuk dikembangkan sebagai komoditas perikanan budidaya, yakni patin jambal (Pangasius djambal), patin nasutus (P. nasutus) dan patin kunyit (P. kunyit) (Pouyaud et al., 1999; Legendre et al., 2000a; Legendre, 2008; IRD, 2009). Namun demikian, spesies patin yang dibudidayakan di Indonesia hingga saat ini terutama hanya patin siam (Pangasianodon hypophthalmus) yang merupakan spesies patin introduksi dan patin jambal yang telah berhasil didomestikasikan, sedangkan patin nasutus dan patin kunyit belum menjadi komoditas perikanan budidaya (pengamatan pribadi).

Budidaya patin di Indonesia dimulai sejak introduksi patin siam dari Thailand pada tahun 1972 yang berhasil dipijahkan secara buatan sejak tahun 1976 (Hardjamulia et al., 1978; 1981). Keunggulan patin siam adalah daya toleransinya yang tinggi terhadap berbagai kondisi kualitas air, fekunditasnya tinggi dan teknik pemijahan buatannya mudah dilakukan serta dapat dipijahkan sepanjang tahun, sehingga budidayanya telah meluas (Cacot, 1998; Legendre et al., 1998b; 1998c; 2000b; Jalabert, 2008). Kekurangan patin siam adalah warna dagingnya yang kuning, sehingga nilainya sebagai komoditas ekspor relatif rendah (Lambert, 2001; Jalabert, 2008).

Patin jambal merupakan spesies patin yang diminati oleh konsumen (Sadili, 1998). Patin jambal berhasil dipijahkan dengan teknik pemijahan buatan pada tahun 1997 di Jambi, dan pada tahun 1999 di Sukamandi melalui proyek Catfish Asia (Legendre et al., 2000a). Teknologi pemijahan buatan dan aspek biologi patin jambal telah telah dipublikasikan oleh Slembrouck et al. (2003a; 2003b), Sudarto (1999); Legendre et al. (1998a; 2000a), dan LRPTBPAT (2006). Namun demikian, patin jambal berfekunditas rendah sehingga upaya pengembangan budidayanya untuk memenuhi kebutuhan ekspor patin daging putih terkendala karena kesulitan dalam upaya penyediaan benih dalam jumlah besar secara berkelanjutan (LRPTBPAT, 2006).

Spesies patin daging putih Indonesia lainnya yang potensial untuk dikembangkan adalah patin nasutus. Uji coba pemijahan buatan patin nasutus telah berhasil dilakukan di Sukamandi (Legendre et al., 2000a), tetapi hingga saat ini masih dalam tahap domestikasi. Upaya pengembangan patin nasutus sebagai komoditas baru perikanan budidaya memerlukan informasi-informasi biologireproduksi berkaitan dengan kapasitas produksinya. Informasi mengenai aspek biologi-reproduksi patin nasutus belum diketahui. Penelitian ini dilakukan dengan tujuan untuk mendapatkan informasi keragaan reproduksi (perkembangan gonad) patin nasutus dengan harapan dapat dikembangkan sebagai komoditas baru perikanan budidaya. 


\section{BAHAN DAN METODE}

\section{Pengamatan Mikroskopis Perkembangan Gonad}

Ikan sampel yang dipergunakan pada penelitian ini adalah koleksi patin nasutus yang dipelihara di kolam percobaan Loka Riset Pemuliaan dan Teknologi Budidaya Perikanan Air Tawar (LRPTBPAT) Sukamandi. Sebanyak 14 ekor betina dan 13 ekor jantan patin nasutus dengan ukuran panjang standar 45,0-54,5 cm dan bobot 1,2-3,0 kg dipelihara dalam kolam tanah berukuran $200 \mathrm{~m}^{2}$. Pakan yang diberikan selama pemeliharaan berupa pelet komersial dengan kadar protein $28 \%$ sebanyak $2 \%$ bobot induk perhari, diberikan dua kali sehari, yakni pada pagi dan sore hari. Pengamatan keragaan reproduksi dilakukan melalui sampling setiap bulan selama periode Desember 2009 sampai Februari 2010.

Identifikasi perkembangan ovari patin nasutus dilakukan melalui pengamatan oosit intraovarian secara mikroskopis. Pengambilan sampel oosit intraovarian dilakukan melalui kanulasi menggunakan kateter khusus (Pipelle de Cornier $^{\mathrm{TM}}$, Laboratoire CCD, Paris, Perancis, www.ccd-lab.com). Sampel hasil kanulasi sebagian langsung diamati dengan menggunakan mikroskop medan terang (Nikon SE ${ }^{\mathrm{TM}}$, Nikon China) yang telah dilengkapi mikrometer (KS ${ }^{\mathrm{TM}}$, Tokyo, Jepang) dan kamera digital (Nikon CoolPix A2100 TM, Jepang), sedangkan sebagian lagi dimasukkan dalam botol sampel berisi larutan fiksatif Bouin's untuk keperluan identifikasi secara histologis.

Karakteristik oosit intraovarian yang diamati antara lain adalah diameter dan tahap perkembangan oosit. Pembagian tahap perkembangan oosit sampel dilakukan dengan mengacu pada hasil penelitian Hardjamulia et al. (1995) yang membagi perkembangan oosit ikan Tor douronensis menjadi lima tahap, yakni tahap I (growth phase= chromatin and perinucleolus, tahap pertumbuhan = kromatin dan perinukleolus), tahap II (yolk vesicles, vesikula kuning telur), tahap III (yolk vesicles and yolk granules, vesikula kuning telur dan granula kuning telur), tahap IV (yolk granules and cortical alveoli, granula kuning telur dan alveoli korteks) dan tahap $\mathrm{V}$ (atretic oocytes, oosit atresis).

Identifikasi perkembangan testis dilakukan melalui pengurutan dan pembedahan testis. Cairan sperma yang diperoleh diamati dengan mikroskop medan terang. Testis hasil pem- bedahan dimasukkan dalam botol sampel berisi larutan fiksatif untuk keperluan identifikasi secara histologis.

\section{Induksi Stimulasi Hormonal}

Induksi stimulasi hormonal dilakukan terhadap induk betina dan jantan patin nasutus yang matang gonad. Penyuntikan untuk induk betina dilakukan dua kali dengan selang waktu penyuntikan selama 24 jam. Penyuntikan pertama dilakukan dengan hormon gonadotropin, yakni hCG (human chorionic gonadotropin) menggunakan CHORULON ${ }^{\circ}$ (Intervet International B.V., European Union) dengan dosis $500 \mathrm{lU} / \mathrm{kg}$ induk. Penyuntikan kedua dilakukan dengan gonadotropin releasing hormone analogue (GnRHa) menggunakan OVAPRIM $^{\star}$ (Syndel Laboratories Ltd. Qualicum Beach, BC Canada, www.syndel.com) dengan dosis $0,6 \mathrm{~mL} / \mathrm{kg}$ induk. Penyuntikan induk jantan dilakukan satu kali bersamaan dengan penyuntikan kedua induk betina menggunakan $\operatorname{OVAPRIM}^{\circ} 0,2 \mathrm{~mL} / \mathrm{kg}$ induk.

\section{Fertilisasi Buatan}

Pengambilan sperma dilakukan melalui pengurutan 10 jam setelah penyuntikan. Sperma hasil pengurutan yang diperoleh diencerkan dengan $0,9 \% \mathrm{NaCl}$ fisiologis dengan perbandingan volume sperma dengan volume larutan garam fisiologis sebanyak 1:5 dan disimpan pada suhu $4^{\circ} \mathrm{C}$ hingga dipergunakan dalam proses fertilisasi. Pengecekan dan pengurutan telur dilakukan 10-15 jam setelah penyuntikan kedua.

Fertilisasi dilakukan dengan metode kering. Sebanyak masing-masing 0,4-0,6 g telur hasil pengurutan ditempatkan dalam wadahwadah plastik bervolume $300 \mathrm{~mL}$ dan segera dicampur dengan sperma dengan cara diaduk menggunakan bulu ayam. Aktivasi proses fertilisasi dilakukan dengan menambahkan 10 $\mathrm{mL}$ air mineral dan diaduk dengan bulu ayam selama sekitar satu menit. Inkubasi dilakukan secara laboratoris dengan media air mineral pada suhu $29-30^{\circ} \mathrm{C}$.

\section{Pemeliharaan Larva}

Larva patin nasutus hasil penetasan dipelihara dalam akuarium bervolume $40 \mathrm{~L}$ dengan kepadatan 20 ekor larva perliter. Selama pemeliharaan, larva diberi pakan berupa nauplii Artemia sp., cacing sutera ( $T u$ bifex sp.) dan pakan komersial bentuk remah dengan kadar protein $40 \%$ secara ad libitum. 


\section{HASIL DAN BAHASAN}

\section{Perkembangan Oosit dan Ovari}

Berdasarkan pengamatan dan karakterisasi secara langsung terhadap sampel oosit intraovarian patin nasutus hasil kanulasi dan terhadap preparat histologis, maka perkembangan oosit intraovarian patin nasutus pada penelitian ini dapat dibagi dalam lima tahap, yakni tahap 1 (tahap kromatin nukleolar dan perinukleolar, chromatin nucleolar and perinucleolar stages), tahap 2 (tahap vesikula kuning telur dan alveoli korteks, yolk vesicles and cortical alveolar stages), tahap 3 (tahap granula kuning telur, yolk granules stage), tahap 4 (tahap migrasi nukleus dan hidrasi, migratory nucleus and hydrated stages) dan tahap 5 (tahap atresis, atretic oocytes stage). Tahap-tahap perkembangan oosit intraovarian patin nasutus tersebut dapat dibedakan karena masing-masing tahap perkembangan memiliki karakteristik yang berbeda, terutama ukuran (diameter) dan penampakannya. Berbeda dengan hasil pada penelitian ini, Hassan (2006) membagi perkembangan oosit intraovarian patin nasutus di Sungai Pahang, Malaysia menjadi sembilan tahap berdasarkan pengamatan secara histologis, yakni tahap oogonia (oogonia stage), tahap folikel primer (primary follicles stage), tahap kromatin nukleolar (chromatin nucleolar stage), tahap perinukleolar (perinucleolar stage), tahap alveoli korteks (cortical alveoli stage), tahap vitelogenesis awal (early vitellogenic stage), tahap vitelogenesis (vitellogenesis stage), tahap vitelogenesis akhir (late vitellogenesis stage) dan tahap atresis (atretic oocytes stage).

Perbedaan pembagian tahap perkembangan oosit intraovarian patin nasutus tersebut terutama dikarenakan perbedaan metode pengamatan yang dipergunakan. Pembagian perkembangan oosit intraovarian patin nasutus di Sungai Pahang dilakukan berdasarkan pada pengamatan secara mikroskopis terhadap preparat histologis, sedangkan pembagian perkembangan oosit intraovarian pada penelitian ini dilakukan berdasarkan perpaduan antara pengamatan secara mikroskopis terhadap preparat histologis dan pengamatan secara mikroskopis terhadap sampel oosit intraovarian segar (fresh oocytes) hasil kanulasi. Namun demikian, karakteristik histologis tahap perkembangan oosit intraovarian patin nasutus di sungai
Pahang tersebut secara umum bersesuaian dengan karakteristik histologis pada penelitian ini. Melalui pengamatan pada preparat histologis dapat diperoleh karakteristik yang lebih detail dan lengkap, sehingga tahap perkembangan oosit intraovarian yang diperoleh juga lebih banyak. Namun demikian, hasil pengamatan preparat histologis tersebut lebih berupa informasi yang tidak dapat langsung diaplikasikan dalam upaya domestikasi dan budidaya (terutama dalam kegiatan seleksi induk dan pemijahan buatan), sehingga informasi tersebut perlu dipadukan dengan informasi karakteristik oosit intraovarian hasil kanulasi yang langsung dapat diaplikasikan dalam kegiatan domestikasi dan budidaya. Dengan kata lain, pengamatan secara langsung terhadap sampel oosit intraovarian hasil kanulasi merupakan pengamatan yang lebih bersifat eksternal dan bertujuan untuk mendapatkan informasi awal dari tahap perkembangan oosit intraovarian patin nasutus. Selanjutnya, informasi tersebut perlu dibandingkan dengan hasil pengamatan secara internal terhadap preparat histologis sebagai pembanding dan penegasan agar hasil-hasil karakteristik tahap perkembangan oosit intraovarian yang diperoleh tersebut bersesuaian dan lebih akurat serta lebih detail. Setelah informasi tahap perkembangan oosit intraovarian patin nasutus secara akurat dan detail telah diperoleh, maka dalam aplikasi kedepannya kegiatan seleksi induk betina yang akan dipergunakan dalam pemijahan buatan dapat dilakukan hanya melalui pengamatan mikroskopis terhadap sampel oosit hasil kanulasi secara langsung.

Oosit tahap 1 patin nasutus berdasarkan pengamatan secara langsung terhadap oosit intraovarian segar hasil kanulasi ditandai dengan penampakan oosit yang tampak jernih seperti kaca (translucent) sampai terlihatnya nukleus yang tampak bergranula dan saling berlekatan satu sama lain (Gambar 1A). Oositoosit tahap 1 patin nasutus tersebut berdiameter kurang dari $0,125 \mathrm{~mm}$. Penampakan oosit tahap 1 patin nasutus tersebut serupa dengan karakteristik oosit utuh (whole oocytes) tahap 1 yang dilaporkan pada ikan Mugil cephalus (Kuo et al., 1974), ikan Lutjanus vittus (Davis \& West, 1993), ikan Selar crumenophthalmus (Suwarso \& Sadhotomo, 1995) dan ikan Hyperogliphe antartica (Baelde, 1996).

Berdasarkan pengamatan terhadap preparat histologis pada penelitian ini, oosit 

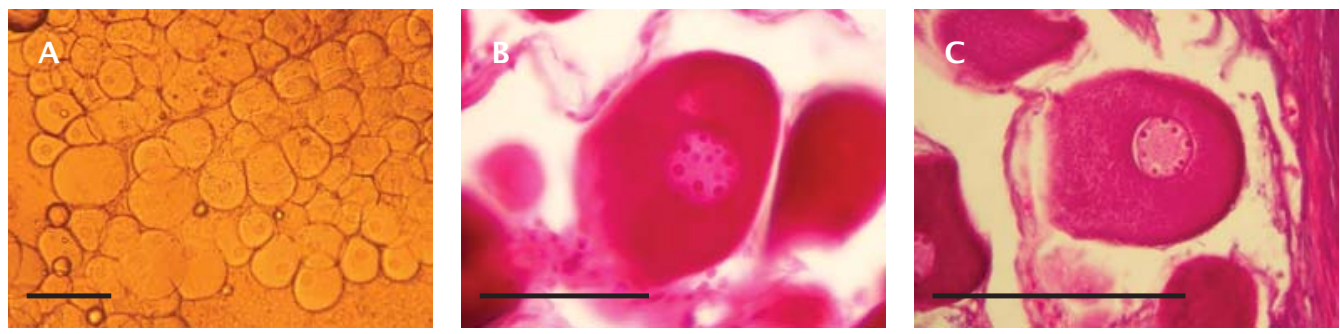

Gambar 1. Oosit tahap 1 hasil kanulasi (A) dan secara histologis (B dan C) (skala batang =0,1 mm)

Figure 1. Stage 1 of the intraovarian oocytes based on biopsy $(A)$ and histological slides ( $B$ and C) samples (bar scale $=0.1 \mathrm{~mm}$ )

tahap 1 patin nasutus ditandai dengan bentuk oosit yang kurang teratur, ooplasma yang berwarna merah-cokelat gelap seluruhnya dengan nukleus berukuran besar dan berisi beberapa nukleoli yang tersebar secara acak di dalamnya (tahap kromatin nukleolar, chromatin nucleolar stage) (Gambar 1B) dan tersusun di perifernya (tahap perinukleolar, perinucleolar stage) (Gambar 1C). Diameter oosit histologis tahap 1 patin nasutus tersebut berdiameter kurang dari 0,100 $\mathrm{mm}$. Karakteristik histologis patin nasutus tersebut serupa dengan karakteristik oosit histologis patin nasutus di Sungai Pahang (Hassan, 2006) dan juga serupa dengan oosit histologis ikan Mugil cephalus (Kuo et al., 1974), ikan Hampala macrolepidota (Abidin, 1986), ikan Tor douronensis (Hardjamulia et al., 1995), ikan Atherestes stomiass (Rickey, 1995), ikan Hyperogliphe antartica (Baelde, 1996) serta ikan Pleurogrammus monopterygius (McDermott \& Lowe, 1997).

Oosit tahap 2 patin nasutus berdasarkan pengamatan secara langsung terhadap sampel oosit intraovarian segar hasil kanulasi ditandai dengan penampakan oosit yang tampak jernih bergranula seluruhnya sampai mulai tampak sedikit buram (transparan, opaque) dengan bagian tengahnya terlihat nukleus yang tampak sebagai bulatan yang lebih gelap (Gambar 2A). Diameter oosit tahap 2 patin nasutus hasil kanulasi berkisar 0,125-0,500 $\mathrm{mm}$. Penampakan oosit patin nasutus hasil kanulasi tersebut serupa dengan karakteristik oosit ikan Lutjanus vittus (Davis \& West, 1995), ikan Selar crumenophthalmus (Suwarso \& Sadhotomo, 1995), ikan Hyperogliphe antartica (Baelde, 1996) dan ikan Puntius bramoides (Iswanto, 2004).

Oosit tahap 2 patin nasutus berdasarkan pengamatan terhadap preparat histologis pada penelitian ini ditandai dengan ooplasma yang terisi vesikula-vesikula kuning telur (yolk vesicles) berwarna merah-kebiruan seluruhnya, kecuali pada bagian tepian oosit yang terisi vesikula-vesikula putih (cortical alveoli) (Gambar 2B). Diameter oosit histologis tahap 2 patin nasutus berkisar 0,100-0,475 mm. Tahap 2 perkembangan oosit intraovarian patin nasutus tersebut merupakan awal tahap pertumbuhan oosit melalui pembentukan material kuning telur (vesikula kuning telur) yang disintesis secara endogen di dalam oosit (direview oleh Nagahama, 1983). Karakteristik histologis oosit tahap 2 patin nasutus tersebut serupa dengan kerakteristik histologis oosit tahap alveoli korteks patin nasutus di Sungai Pahang (Hassan, 2006) dan juga serupa dengan karakteristik oosit ikan Hyperogliphe antartica (Baelde, 1996).

Oosit tahap 3 patin nasutus berdasarkan pengamatan secara langsung terhadap sampel oosit intraovarian segar hasil kanulasi ditandai dengan ooplasma yang seluruhnya buram sampai oosit seluruhnya tampak gelap, kecuali pada bagian tepian oosit (perivitelline border) dan nukleus di tengah-tengah oosit yang tampak lebih jernih (terang) (Gambar 3A). Diameter oosit tahap 3 patin nasutus hasil kanulasi berkisar 0,700-1,850 mm. Penampakan oosit patin nasutus tersebut serupa dengan karakteristik oosit ikan Lutjanus vittus (Davis \& West, 1995), ikan selar crumenophthalmus (Suwarso \& Sadhotomo, 1995), ikan Hyperogliphe antartica (Baelde, 1996) dan ikan Puntius bramoides (Iswanto, 2004).

Berdasarkan pengamatan terhadap preparat histologis, oosit tahap 3 patin nasutus ditandai dengan ooplasma yang terisi butirbutir granula kuning telur berwarna kemerahmerahan mulai dari bagian tengah di sekitar nukleus hingga hampir ke bagian tepi 

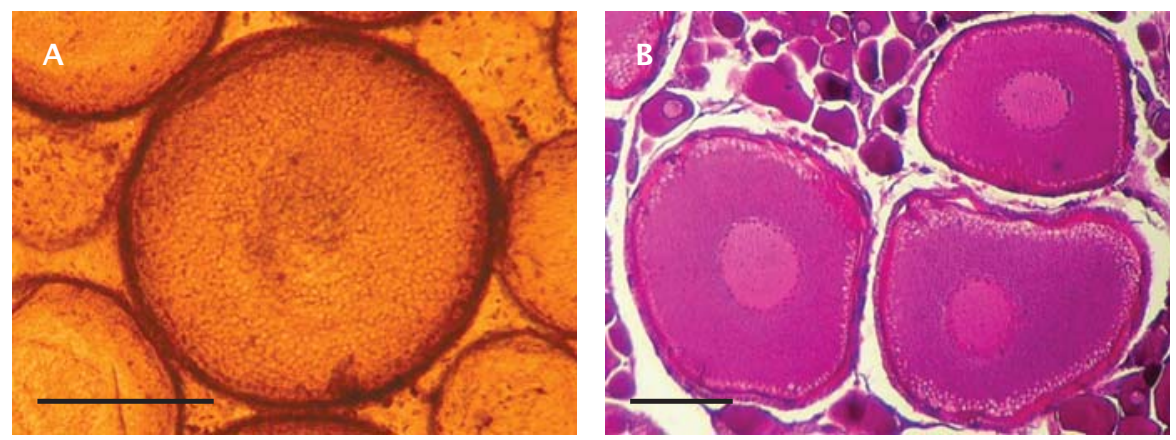

Gambar 2. Oosit tahap 2 hasil kanulasi (A) dan secara histologis (B) (skala batang= $0,1 \mathrm{~mm})$

Figure 2. Stage 2 of the intraovarian oocytes based on biopsy $(A)$ and histological slide $(B)$ samples (bar scale $=0.1 \mathrm{~mm}$ )

ooplasma, kecuali bagian tepian oosit yang masih berupa vesikula-vesikula putih (alveoli korteks) dan nukleus masih di tengah (Gambar 3B). Diameter oosit histologis tahap 3 patin nasutus berkisar 0,600-1,700 mm. Karakteristik histologis oosit tahap 3 patin nasutus tersebut serupa dengan karakteristik histologis oosit patin nasutus di Sungai Pahang pada tahap vitelogenesis awal dan tahap vitelogenesis (Hassan, 2006). Karakteristik yang diberikan para peneliti pada oosit tahap ini serupa, hanya istilahnya kadang-kadang berbeda, antara lain yolk stage, yolk globule stage, vitellogenic stage. Tahap 3 perkembangan oosit intraovarian patin nasutus tersebut merupakan tahap pembentukan (deposisi) material kuning telur (granula kuning telur) yang disintesis secara eksogen di hati (vitelogenesis) (direview oleh Nagahama, 1983).

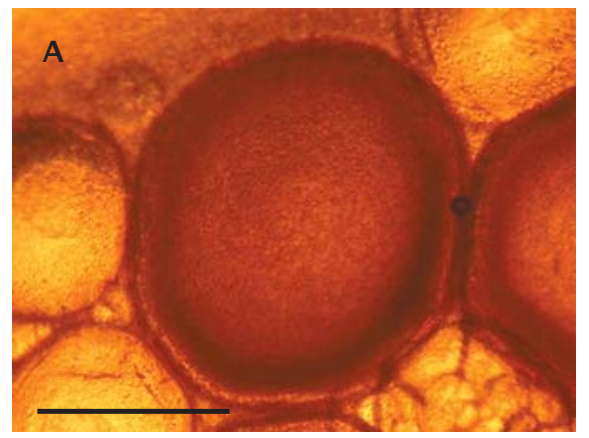

Oosit tahap 4 patin nasutus berdasarkan pengamatan secara langsung pada sampel oosit intraovarian segar hasil kanulasi ditandai dengan bagian tepi ooplasma yang tampak mulai jernih (tahap migrasi nukleus, migratory nucleus stage) sampai oosit yang seluruh bagiannya tampak jernih (tahap hidrasi, hydrated oocyte stage) (Gambar 4A). Diameter oosit tahap 4 patin nasutus hasil kanulasi berkisar 1,250-1,900 mm. Oosit tahap 4 jarang terjadi pada ovari patin nasutus yang belum mendapatkan stimulasi hormonal untuk proses pematangan tahap akhir atau kadang-kadang dapat ditemukan dalam ovari selama periode yang bertepatan dengan musim pemijahannya, tetapi dalam jumlah yang sangat sedikit. Hal ini dikarenakan oosit tahap 3 patin nasutus segera mengalami atresia jika tidak mendapatkan cukup stimulasi.

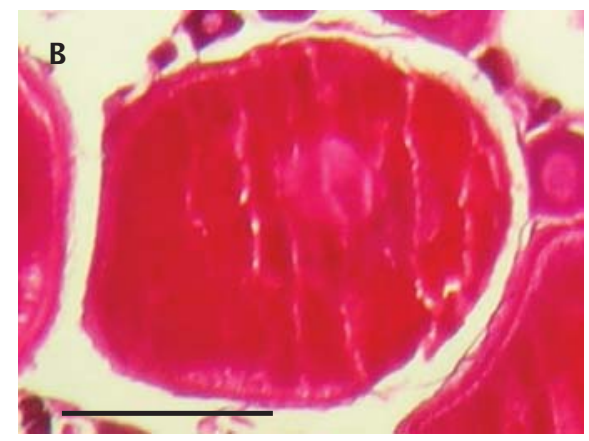

Gambar 3. Oosit tahap 3 hasil kanulasi (A) dan secara histologis (B) (skala batang $=$ $0,5 \mathrm{~mm})$

Figure 3. Stage 3 of the intraovarian oocytes based on biopsy $(A)$ and histological slide ( $B$ and $C$ ) samples (bar scale $=0.5 \mathrm{~mm}$ ) 

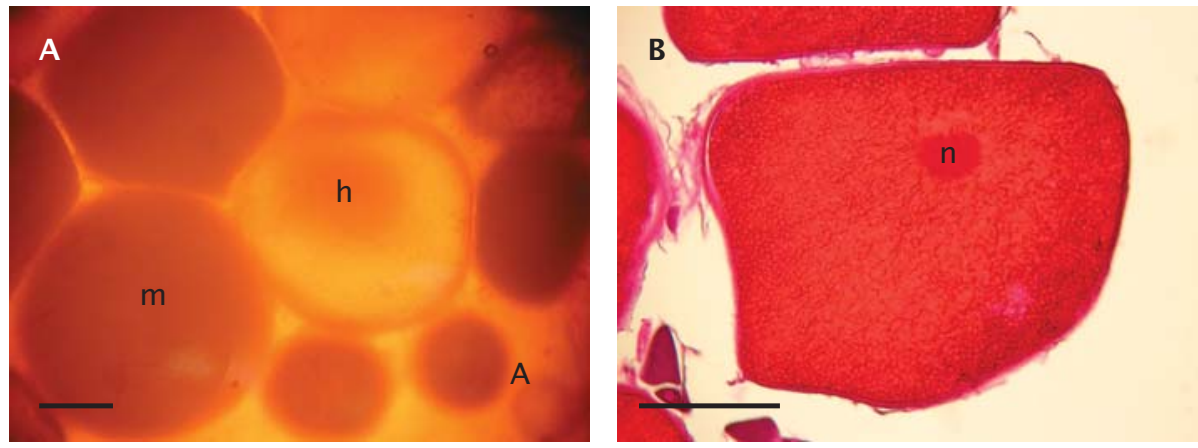

Gambar 4. Oosit tahap 4 hasil kanulasi (A) dan secara histologis (B) $(m=$ tahap migrasi nukleus, $\mathrm{h}=$ tahap terhidrasi, $\mathrm{n}=$ nukleus, skala batang $=0,5 \mathrm{~mm}$ )

Figure 4. Stage 4 of intraovarian oocytes based on biopsy $(A)$ and histological slide $(B$ and $C$ ) samples ( $m=$ migratory nucleus stage, $h=$ hydrated stage, $n=$ nucleus, bar scale $=0.5 \mathrm{~mm}$ )

Berdasarkan pengamatan pada preparat histologis pada penelitian ini, oosit tahap 4 patin nasutus ditandai penampakan yang serupa dengan oosit tahap 3, tetapi nukleus sudah terletak di salah satu tepian oosit (tahap migrasi nukleus, migratory nucleus stage) (Gambar 4B). Diameter oosit histologis tahap migrasi nukleus patin nasutus berkisar 1,100$1,750 \mathrm{~mm}$. Oosit tahap hidrasi (hydrated oocyte stage) tidak dapat dibuat preparat histologisnya, karena saat diiris menjadi pecah-pecah. Karakteristik oosit histologis tahap migrasi nukelus patin nasutus tersebut serupa dengan karakteristik oosit patin nasutus di sungai Pahang pada tahap vitelogenesis akhir (Hassan, 2006).

Oosit tahap 5 patin nasutus berdasarkan pengamatan secara langsung pada sampel oosit intraovarian segar hasil kanulasi ditandai dengan penampakan oosit yang berbentuk tidak teratur, tidak bulat dan tampak tidak kompak, tampak buram, transparan sampai gelap bergranula (Gambar 5A dan 5B). Oosit tahap 5 patin nasutus merupakan hasil perkembangan tahap-tahap oosit yang lain yang mengalami degenerasi. Oosit tahap 5 patin nasutus tersebut berukuran lebih kecil daripada diameter oosit pada tahap perkembangan normalnya, yakni berkisar 0,300-1,700 mm.

Berdasarkan pengamatan pada preparat histologis, oosit atresis patin nasutus tampak ditandai dengan oolema (zona radiata) yang tidak teratur dan pada beberapa bagian mengalami penebalan, serta tampak butir-butir kuning telur tersisa sedikit di bagian tengah oosit, sedangkan pada bagian tepian oosit tampak bervakuola yang merupakan sisa-sisa penyerapan (Gambar 5C). Oosit histologis tahap 5 patin nasutus berukuran lebih kecil dari $0,700 \mathrm{~mm}$. Karakteristik oosit tahap 5 patin nasutus tersebut serupa dengan karakteristik
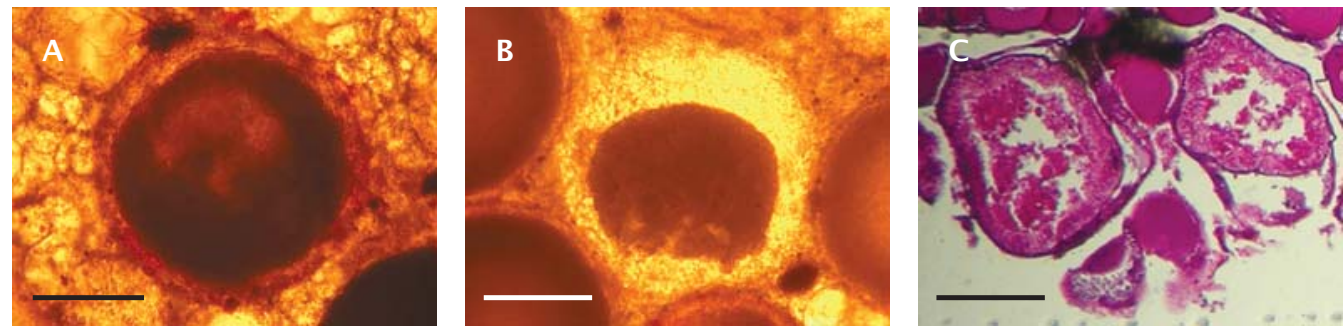

Gambar 5. Oosit tahap 5 hasil kanulasi (A dan B) dan secara histologis (C) (skala batang=0,5 mm)

Figure 5. Stage 5 of intraovarian oocytes based on biopsy (A and B) and histological slide (C) samples (bar scale $=0.5 \mathrm{~mm}$ ) 
tahap atresis patin nasutus di sungai Pahang (Hassan, 2006) dan juga serupa dengan karakteristik oosit atresis ikan Mugil cephalus (Kuo et al., 1974), ikan Tor douronensis (Hardjamulia et al., 1995) serta ikan Puntius bramoides (Iswanto, 2004).

Berdasarkan komposisi tahap perkembangan oosit intraovariannya (Gambar 6), maka perkembangan ovari $(T K G=$ tingkat kematangan gonad) patin nasutus dapat dibagi menjadi lima tingkat, yakni TKG I (belum berkembang atau muda, immature), TKG II (perkembangan, developing), TKG III (pematangan, maturing), TKG IV (matang, mature) dan TKG V (salin atau regresi, spent). Pembagian tingkat perkembangan ovari patin nasutus tersebut dilakukan berdasarkan keberadaan tahap perkembangan oosit tertua dalam ovarinya, seperti yang dilakukan oleh Hardjamulia et al. (1995) pada ikan Tor douronensis. Hassan (2006) membagi perkembangan kematangan ovari patin nasutus di Sungai Pahang menjadi enam tingkat, yakni salin (resting), pematangan (maturing), matang (mature), siap memijah (spawning), sedang memijah (running) dan selesai memijah (spent). Secara umum, terdapat perbedaan pembagian tingkat perkembangan ovari patin nasutus pada penelitian ini dengan patin nasutus di Sungai Pahang. Hasil penelitian keragaan reproduksi patin nasutus di Sungai Pahang menunjukkan adanya sampel patin nasutus yang dalam kondisi memijah, sedangkan pada penelitian ini tidak ditemukan. Perbedaan tersebut tentunya dikarenakan perbedaan lingkungan asal sampel patin nasutus yang dipergunakan, yakni sampel patin nasutus yang diamati pada penelitian ini berada di lingkungan budidaya (kolam), sehingga tidak dapat mencapai kondisi matang gonad secara sempurna dan tidak dapat memijah, berbeda dengan patin nasutus di Sungai Pahang yang merupakan habitat patin nasutus.

Ovari tingkat I merupakan tingkat perkembangan ovari patin nasutus yang paling muda. Komposisi oosit intraovarian ovari tingkat I seluruhnya berupa oosit tahap 1. Ovari tingkat I selanjutnya berkembang menjadi ovari tingkat II, dengan sebagian oosit tahap 1 berkembang menjadi oosit tahap 2 (28,6\%). Ovari tingkat II selanjutnya berkembang menjadi ovari tingkat III, dengan adanya dominasi oosit tahap $1(43,7 \%)$ dan oosit tahap $3(46,4 \%)$ serta sedikit oosit tahap $2(9,1 \%)$. Ovari tingkat III selanjutnya berkembang menjadi ovari tingkat IV, dengan oosit tertua berupa oosit tahap 4. Namun demikian, ovari patin nasutus pada penelitian ini tidak pernah mencapai ovari tingkat IV secara sempurna, terlihat dari hanya sedikitnya komposisi oosit tahap 4 (2,3\%), dengan tetap adanya dominasi oosit tahap 1 $(42,6 \%)$ dan oosit tahap $3(48,1 \%)$ serta sedikit

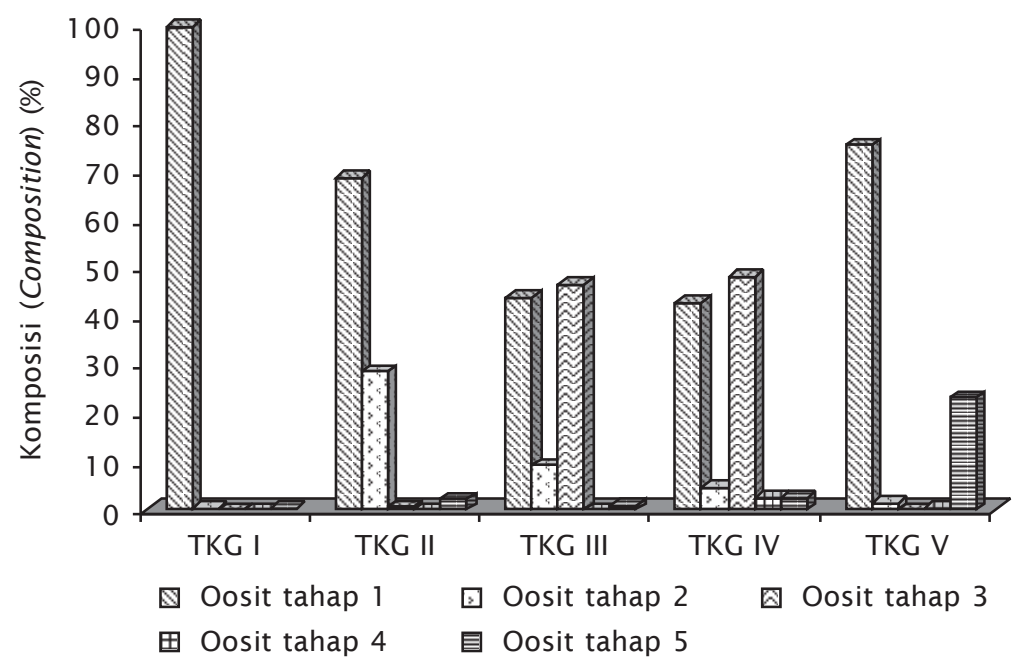

Gambar 6. Komposisi oosit intraovarian pada berbagai TKG

Figure 6. Composition of the intraovarian oocytes at various stages of ovarian maturity 
oosit tahap $2(4,6 \%)$. Ovari tingkat IV patin nasutus selanjutnya berkembang menjadi ovari tingkat $\mathrm{V}$, dengan adanya tingkat atresia yang tinggi $(23,1 \%)$. Namun demikian, ovari patin nasutus tingkat III dan ovari tingkat IV yang kurang sempurna tersebut jika mendapat induksi stimulasi hormonal dapat berkembang menjadi ovari tingkat IV secara sempurna, dengan adanya dominasi oosit tahap 4 (tahap terhidrasi) (Gambar 7).

Hasil pengamatan perkembangan oosit dan ovari patin nasutus pada penelitian ini menunjukkan bahwa oosit intraovarian tahap 3 merupakan tahap perkembangan oosit tertua yang dapat mengalami perkembangan secara sempurna, sedangkan oosit tahap 4 hanya dapat ditemukan dalam jumlah yang sedikit dengan tingkat atresia yang cukup tinggi, mengindikasikan bahwa perkembangan oosit tahap 3 menjadi oosit tahap 4 sulit terjadi secara sempurna. Hasil tersebut juga menunjukkan bahwa oosit tahap 3 merupakan oosit yang responsif terhadap induksi stimulasi hormonal. Dengan demikian, pemijahan buatan patin nasutus dapat dilakukan melalui induksi stimulasi hormonal terhadap induk betina dengan komposisi oosit intraovarian yang didominasi oleh oosit tahap 3, yakni secara mikroskopis berdasarkan sampel hasil kanulasi ditandai dengan penampakan oosit yang seluruhnya tampak gelap dan berdiameter 0,700-1,850 mm. Namun demikian, oosit tahap 3 yang masih berukuran kecil tentunya kurang responsif terhadap stimulasi hormonal, sehingga agar tingkat keberhasilan pemijahan buatan dapat

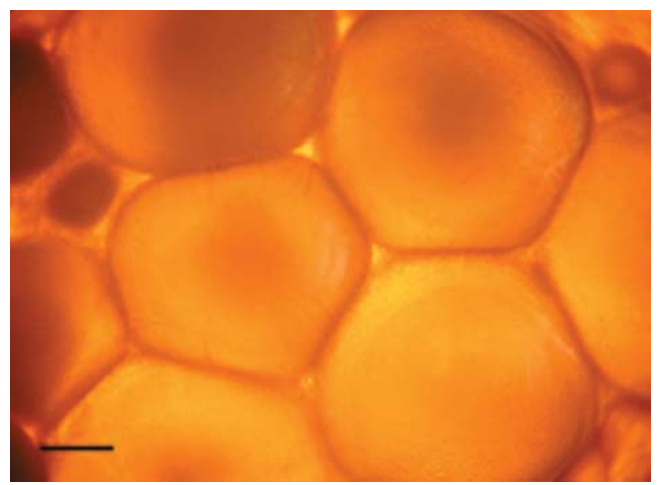

Gambar 7. Ovari tingkat IV hasil stimulasi hormonal (skala batang $=0,5 \mathrm{~mm}$ )

Figure 7. Stage IV of hormonally induced ovary (bar scale $=0.5 \mathrm{~mm}$ ) lebih tinggi, maka perlu dilakukan seleksi induk betina dengan memilih induk-induk betina patin nasutus yang memiliki oosit tahap 3 dengan diameter yang besar, setidaknya lebih besar dari 1,3 mm. Diameter oosit intraovarian patin nasutus yang dapat dipergunakan dalam stimulasi hormonal dan pemijahan buatan tersebut sedikit lebih kecil daripada patin jambal dan ikan patin $P$. bocourti. Induksi stimulasi hormonal dapat dilakukan terhadap betina ikan patin $P$. bocourti di delta Mekong, Vietnam yang memiliki diameter oosit intraovarian lebih dari 1,6 $\mathrm{mm}$ dan tidak berhasil dilakukan pada betina yang berdiameter oosit kurang dari 1,3 mm (Cacot, 1998; Cacot et al., 2002). Demikian pula, induksi stimulasi hormonal dapat dilakukan terhadap betina patin jambal di Jambi yang memiliki diameter oosit sama dengan atau lebih besar dari 1,55-1,60 mm, sedangkan betina dengan oosit yang berdiameter lebih kecil tidak responsif terhadap stimulasi hormonal (Legendre et al., 1998a). Diameter oosit intraovarian patin siam yang dapat dipergunakan dalam proses pemijahan buatan di Sukamandi (Legendre et al., 1998b) dan di delta Mekong (Cacot, 1998) berukuran lebih kecil, yakni lebih besar dari 1,0 mm, sedangkan ikan patin $P$. conchophilus yang dapat dipijahkan secara buatan di delta Mekong memiliki diameter oosit intraovarian yang sedikit lebih kecil, yakni berkisar 0,96-1,04 mm (Xuan \& Liem, 1998).

Hasil penelitian ini menunjukkan bahwa perkembangan oosit intraovarian patin nasutus bersifat sinkronis grup (group synchronism), ditandai dengan keberadaan dominasi dua kelompok oosit dalam ovari ikan yang siap memijah (ovari tingkat III dan IV), yakni kelompok oosit tertua (oosit tahap 3) yang (seharusnya) akan segera dikeluarkan pada saat pemijahan waktu itu dan kelompok oosit stok yang belum berkuning telur dan berukuran kecil (oosit tahap 1) yang merupakan telur cadangan untuk proses pemijahan berikutnya. Hasil penelitian Hassan (2006) juga menunjukkan bahwa tipe perkembangan oosit intraovarian patin nasutus di Sungai Pahang bersifat sinkronis grup. Ovari patin nasutus dengan oosit intraovarian yang bersifat sinkronis grup tersebut mengindikasikan bahwa dalam satu musim pemijahan patin nasutus dapat memijah lebih dari satu kali. Kepastian frekuensi pemijahan patin nasutus dalam suatu musim pemijahan tersebut memerlukan penelitian lebih lanjut 
tentang siklus reproduksi tahunannya. Hasil penelitian Cacot (1998) menunjukkan bahwa patin siam dan ikan patin $P$. bocourti di delta Mekong yang tipe perkembangan oosit intraovariannya juga bersifat sinkronis grup dapat memijah dua kali dalam setahun.

\section{Fekunditas}

Perkembangan oosit patin nasutus bersifat sinkronis grup, sama seperti patin siam, sehingga patin nasutus juga potensial dan prospektif dari aspek produktivitasnya. Hal ini dikarenakan pada setiap proses pemijahan, tingkat keberhasilan ovulasi dan jumlah telur yang dihasilkan (fekunditas) tinggi, sehingga memungkinkan dalam proses produksi massal benihnya. Jumlah telur yang diovulasikan (hasil pengurutan) perbobot induk betina patin nasutus (fekunditas relatif) hasil induksi stimulasi hormonal pada penelitian ini berkisar 26-67 butir telur per gram bobot induk, dengan fekunditas mutlak berkisar 39.273-145.989 butir telur pada induk betina berbobot 1,2-3,0 $\mathrm{kg}$. Fekunditas relatif patin nasutus tersebut relatif lebih tinggi daripada patin jambal, tetapi lebih rendah daripada patin siam. Pada waktu dan tempat serta metode pemeliharaan yang sama, induk betina patin jambal memiliki fekunditas relatif yang hanya berkisar 3-4 butir telur per gram bobot induk, sedangkan fekunditas relatif patin siam jauh lebih tinggi, yakni mencapai 120-175 butir telur pergram bobot induk (hasil pengamatan pribadi). Fekunditas relatif patin jambal yang dipergunakan dalam pemijahan buatan di Jambi sebesar 2.737 butir telur per kilogram bobot induk (Legendre et al., 1998a). Patin jambal merupakan spesies patin berfekunditas rendah, sedangkan fekunditas patin siam sangat tinggi (LRPTBPAT, 2006). Hasil penelitian Legendre et al. (1998b; 2000 b) juga menunjukkan bahwa fekunditas relatif patin siam di Sukamandi sangat tinggi, yakni sebesar $128 \pm 60$ butir telur per kilogram bobot induk berdasarkan hasil stimulasi hormonal menggunakan hCG dan sebesar $171 \pm 73$ butir telur per gram bobot induk berdasarkan hasil stimulasi hormonal menggunakan ovaprim. Fekunditas relatif patin siam hasil induksi stimulasi hormonal di delta Mekong bervariasi, berkisar 5.500-297.500 butir telur perkilogram bobot induk (Cacot, 1998), sedangkan fekunditas ikan patin $P$. bocourti jauh lebih rendah, yakni berkisar 400-16.700 butir telur perkilogram bobot induk (Cacot et al., 2002). Ikan patin P. conchophilus di delta Mekong memiliki fekunditas relatif yang berkisar 25.714-32.882 butir telur per kilogram bobot induk (Xuan \& Liem, 1998).

\section{Sperma}

Sperma patin nasutus hasil pengurutan pada penelitian ini menunjukkan motilitas yang tinggi (Gambar 8A). Hasil pengamatan terhadap preparat histologis testis menunjukkan bahwa perkembangan sel gamet jantan patin nasutus bersifat asinkronis (asynchronism), ditandai dengan keberadaan berbagai tahap perkembangan sel gamet jantan, mulai spermatogonia, spermatosit hingga spermatozoa (Gambar 8B). Tipe perkembangan testis patin nasutus yang bersifat asinkronis tersebut serupa dengan tipe perkembangan testis spesies-spesies ikan yang lain (direview oleh Mananos et al., 2009).
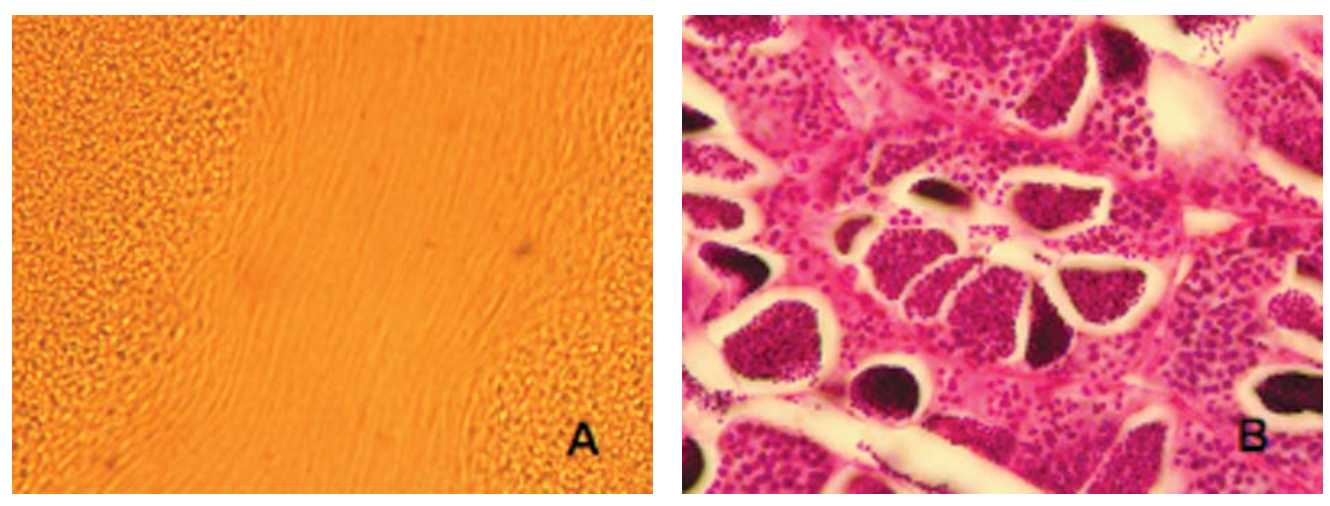

Gambar 8. Motilitas sperma hasil kanulasi (A) dan testis matang histologis (B)

Figure 8. Motilities of the stripped sperm (A) and histological slide of mature testis (B) 
Sperma patin nasutus hasil pengurutan yang sebelumnya telah mendapat stimulasi hormonal menggunakan ovaprim memiliki kualitas yang bagus. Hal tersebut terlihat dari evaluasi (perbandingan) derajat fertilisasi, penetasan dan deformitas larva patin siam, nasutus, jambal beserta hibrida-hibrida hasil hibridisasi antara betina patin siam dengan jantan patin jambal dan jantan patin nasutus yang menunjukkan bahwa oosit dari induk betina patin siam yang sama yang difertilisasi dengan sperma patin nasutus menghasilkan derajat fertilisasi dan penetasan yang lebih tinggi dengan derajat deformitas larva yang lebih rendah daripada derajat fertilisasi, penetasan dan deformitas larva yang difertilisasi dengan sperma patin siam maupun patin jambal, mengindikasikan bahwa kualitas sperma patin nasutus relatif lebih bagus daripada sperma patin siam maupun patin jambal (Iswanto, 2011). Hasil tersebut menunjukkan bahwa kualitas sperma patin nasutus bahkan lebih bagus daripada sperma patin jambal yang seringkali dinyatakan memiliki kualitas yang bagus (LRPTBPAT, 2006; Legendre et al., 2008).

\section{Pemijahan Buatan dan Larva}

Hasil derajat penetasan larva patin nasutus pada penelitian ini berkisar 44,16-79,05\% dengan lama inkubasi berkisar 22-25 jam pada suhu media inkubasi $29-30^{\circ} \mathrm{C}$. Perkembangan embrio dan perkembangan ontogeni morfologis larva patin nasutus telah dideskripsikan (Tahapari et al., 2010; Iswanto, 2011). Ukuran panjang total larva patin nasutus yang baru menetas pada penelitian ini berkisar
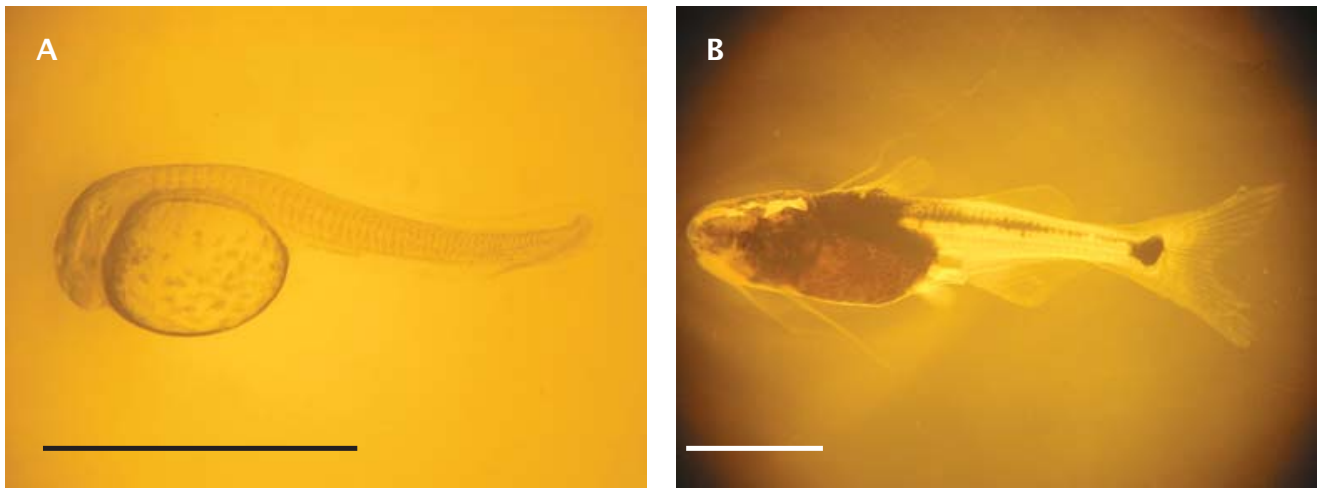

Gambar 9. Larva patin nasutus yang baru menetas (A) dan umur 10 hari (B) (skala batang= $3 \mathrm{~mm}$ )

Figure 9. Newly hatched $(A)$ and 10 days old $(B)$ larvae of $P$. nasutus (bar scale $=3 \mathrm{~mm}$ ) 


\section{KESIMPULAN DAN SARAN}

Hasil penelitian ini menunjukkan bahwa patin nasutus cukup potensial dan prospektif dari aspek produktivitas (dalam rangka produksi massalnya) sebagai komoditas andalan baru perikanan budidaya. Oleh karena itu, perlu dilakukan penelitian-penelitian lebih lanjut dalam mendukung upaya domestikasi dan pengembangan budidayanya.

\section{UCAPAN TERIMA KASIH}

Penulis menyampaikan rasa terima kasih dan penghargaan yang sebesar-besarnya kepada Kamlawi, Komar, dan Oman Iskandar selaku teknisi komoditas riset patin LRPTBPAT Sukamandi, atas bantuan teknisnya selama kegiatan pemeliharaan induk, sampling, pemijahan buatan dan pemeliharaan larva.

\section{DAFTAR ACUAN}

Abidin, A.Z. 1986. Aspect of the biology of a tropical cyprinid, Hampala macrolepidota (Van Hasselt), with preference to food, feeding habits, and reproduction. In: J.L. McLean and L.V. Hossilos (eds.). The First Asian Fisheries Forum. Asian Fisheries Society. Manila, p. 515-518.

Baelde, P. 1996. Biology and dynamics of the reproduction of blue-eye trevalla, Hyperogliphe antartica (Centrolophidae), off Tasmania, Southern Australia. Fishery Bulletin, 94(2): 199-211.

Cacot, P. 1998. Description of the sexual cycle related to the environment and set up of the artificial propagation in Pangasius bocourti (Sauvage, 1880) and Pangasius hypophthalmus (Sauvage, 1878) reared in floating cages and ponds in the Mekong Delta. In: M. Legendre and A. Parisele (eds.). The Biological Diversity and Aquaculture of Clariid and Pangasiid Catfishes in SouthEast Asia. Proceeding of The Mid-Term Workshop of the Catfish Asia Project, 1 1-15 May 1998. Cantho-Vietnam, p. 71-89.

Cacot, P., Legendre, M., Dan, T.Q., Tung, L.T., Liem, P.T., Mariojouls, C., \& Lazard, J. 2002. Induced ovulation of Pangasius bocourti (Sauvage, 1880) with a progressive hCG treatment. Aquaculture, 213: 199-206.

Davis, T.L.O. \& West, G.J. 1993. Maturation, reproductive seasonality, fecundity, and spawning frequency in Lutjanus vittus (Quoy and Gaimard) from the North West
Shelf of Australia. Fishery Bulletin, 91(2): 224-236.

Gustiano, R. 2009. Pangasiid catfishes of Indonesia. Buletin Plasma Nutfah, 15(2): 91-100.

Hardjamulia, A., Atmawinata, S., \& Suseno, D. 1978. Penelitian pembenihan ikan jambal siam (Pangasius sutchi F). Pewarta LPPD Tahun ke-1 No. 1, Agustus-Desember 1978. Lembaga Penelitian Perikanan Darat (LPPD). Badan Penelitian dan Pengembangan Pertanian, $4 \mathrm{hlm}$.

Hardjamulia, A., Djajadiredja, R., Atmawinata, S., \& Idris, D. 1981. Pembenihan jambal siam (Pangasius sutchi) dengan suntikan ekstrak kelenjar hipofisa ikan mas (Cyprinus carpio). Buletin Penelitian Perikanan, I(2): 183-190.

Hardjamulia, A., Suhenda, N., \& Wahyudin, E. 1995. Perkembangan oosit dan ovari ikan semah (Tor douronensis) di sungai selabung, Danau Ranau, Sumatera Selatan. J. Pen. Perik. Indonesia, I(3): 36-46.

Hassan, M.Z. 2006. Morphology and general reproductive stages of Pangasius nasutus from sg. Pahang in District Maran, Pahang, Malaysia. Master of Science Thesis. Universiti Putra Malaysia, 139 pp.

IRD. 2009. Biodiversity and aquaculture of catfishes in South East Asia. Institute de Recherce pour le Developpement (IRD), France. www.ird.fr (diakses pada tanggal 20 Nopember 2009 pukul 11.18 WIB).

Islam, A. 2005. Embryonic and larval development of Thai Pangas (Pangasius sutchi Fowler, 1937). Development, Growth and Differentiation, 47: 1-6.

Iswanto, B. 2004. Studi kematangan gonad dan fekunditas ikan baderbang (Puntius bramoides C.V.) melalui pengamatan dan pengukuran diameter oositnya. Skripsi. Budidaya Perairan. Fakultas Perikanan. Universitas Brawijaya. Malang, $92 \mathrm{hlm}$ (tidak dipublikasikan).

Iswanto, B. 2011 . Hibridisasi antara betina patin siam (Pangasianodon hypophthalmus Sauvage, 1878) dengan jantan patin nasutus (Pangasius nasutus Bleeker, 1863) dalam upaya meningkatkan produktivitas patin daging putih. Tesis. Program Magister Bioteknologi Perikanan dan Kelautan. Fakultas Perikanan dan Ilmu Kelautan. Universitas Brawijaya. Malang. $218 \mathrm{hlm}$. (tidak dipublikasikan). 
Jalabert, B. 2008. An overview of 30 years international research in some selected fields of the reproductive physiology of fish. Cybium, 32(2): 7-13.

Khan, M.H.K. \& Mollah, M.F.A. 2004. Further trials on induced breeding of Pangasius pangasius (Hamilton) in Bangladesh. Asian Fisheries Science, 17: 135-146.

Kuo, C.-M., Nash, C.E., \& Shehadeh, Z.H. 1974. A procedural guide to induce spawning in Grey Mullet (Mugil cephalus L.). Aquaculture, 3: 1-14.

Lambert, D. 2001. Tonle Sap fisheries: a case study on floodplain gillnet fisheries in Siem Riep, Cambodia. RAP Publication 2001/11. Food and Agricultural Organization of the United Nations. Regional Office for Asia and the Pacific. Bangkok, 141 pp.

Legendre, M., Slembrouck, J., \& Subagja, J. 1998a. First result on growth and artificial propagation of Pangasius djambal (Siluriformes, Pangasiidae) in Indonesia. In: M. Legendre and A. Parisele (eds.). The Biological Diversity and Aquaculture of Clariid and Pangasiid Catfishes in South-East Asia. Proceeding of The Mid-Term Workshop of the Catfish Asia Project, 11-15 May 1998. Cantho-Vietnam, p. 97-102.

Legendre, M., Slembrouck, J., Subagja, J., \& Kristanto, A.H. 1998b. Effect of varying latency period on the in vivo survival of ova after Ovaprim- and hCG-induced ovulation in the Asian catfish Pangasius hypophthalmus (Pangasiidae, Siluriformes). In: M. Legendre and A. Parisele (eds.). The Biological Diversity and Aquaculture of Clariid and Pangasiid Catfishes in SouthEast Asia. Proceeding of The Mid-Term Workshop of the Catfish Asia Project, 1 1-15 May 1998. Cantho-Vietnam, p. 119-125.

Legendre, M., Subagja, J., \& Slembrouck, J. 1998c. Absence of marked seasonal variations in sexual maturity of Pangasius hypophthalmus brooders held in Sukamandi Station (Java, Indonesia). In: M. Legendre and A. Parisele (eds.). The Biological Diversity and Aquaculture of Clariid and Pangasiid Catfishes in South-East Asia. Proceeding of The Mid-Term Workshop of the Catfish Asia Project, 1 1-15 May 1998. Cantho-Vietnam, p. 91-96.

Legendre, M., Pouyaud, L., Slembrouck, J., Gustiano, R., Kristanto, A.H., Subagja, J., Komarudin, O., Sudarto, \& Maskur. 2000a. Pangasius djambal: a new candidate species for fish culture in Indonesia. Indonesian Agricultural Research and Development Journal, 22(1): 1-14.

Legendre, M., Slembrouck, J., Subagja, J., \& Kristanto, A.H. 2000b. Ovulation rate, latency period and ova viability after GnRH- or hCG-induced breeding in the Asian catfish Pangasius hypophthalmus (Siluriformes, Pangasiidae). Aquatic Living Resources, 13: 145-151.

Legendre, M. 2008. Characterisation, utilisation and maintenance of biological diversity for the diversification and sustainability of catfish culture in SouthEast Asia. In: N. Estrella Santos and C.E. Nauen (eds.). Catalogue of Synopses of International S\&T Cooperative (INCO) Projects on Chalenges in Fisheries, Coastal Zones, Wetlands and Aquaculture. ACP-EU Fisheries Resources Report,17: 206-207.

Legendre, M., Cosson, J., \& Subagja, J. 2008. Sperm characteristics and motility in Pangasianodon hypophthalmus (Sauvage, 1878) and Pangasius djambal Bleeker, 1846 (Pangasiidae, Siluriformes). Cybium, 32(2): 183-184.

LRPTBPAT. 2006. Dokumen Usulan Pelepasan Patin Hibrida. Loka Riset Pemuliaan dan Teknologi Budidaya Perikanan Air Tawar. Loka Riset Pemuliaan dan Teknologi Budidaya Perikanan Air Tawar (LRPTBPAT). Sukamandi, $14 \mathrm{hlm}$.

Mananos, E., Duncan, N., \& Mylonas, E. 2009. Reproduction and control of ovulation, spermiation and spawning in cultured fish. In: E Cabrita, V Robles and P Herraez (eds.). Methods in Reproductive Aquaculture, Marine and Freshwater Species. CRC Press. Boca Raton-London-New York, p. 3-80.

McDermott, S.F. \& Lowe, S.A. 1997. The reproductive cycle and sexual maturity of Atka Mackerel, Pleurogrammus monopterygius in Alaska Waters. Fishery Bulletin, 95(2): 321-333.

Nagahama, Y. 1983. The functional morphology of teleost gonads. In: W.S. Hoar, D.J. Randall and E.M. Donaldson (eds.). Fish Physiology, volume IX Reproduction, Part A. Academic Press. New York-London-ParisSan Diego-Sao Paulo-Sydney-TokyoToronto, p. 234-275.

Nurdjana, M.L. 2006. Indonesian aquaculture development. Paper in: RCA International Workshop on Innovative Technologies for Eco-Friendly Fish Farm Management and 
Production of Safe Aquaculture Foods, Bali, 4-8 December 2006, 22 pp.

Pouyaud, L., Teugels, G.G., \& Legendre, M. 1999. Description of a new pangasiid catfish from South-East Asia (Siluriformes). Cybium, 23(3): 247-258.

Rickey, M.H. 1995. Maturity, spawning, and seasonal movement of arrowtooth flounder, Atheresthes stomiass, off Washington. Fishery Bulletin, 93(1): 127-128.

Roberts, T.R. \& Vidthayanon, C. 1991. Systematic revision of the Asian catfish family Pangasiidae, with biological observations and description of three new species. Proceedings of the Academy of Natural Sciences of Philadelphia, 143: 97-144.

Sadili, D. 1998. Marketing of pangasiid catfishes in Java and Sumatera, Indonesia. In: M Legendre and A Parisele (eds.). The Biological Diversity and Aquaculture of Clariid and Pangasiid Catfishes in SouthEast Asia. Proceeding of The Mid-Term Workshop of the Catfish Asia Project, 1 1-15 May 1998. Cantho-Vietnam, p. 21-26.

Slembrouck, J., Subagja, J., Day, D., Firdausi, \& Legendre, M. 2003a. Artificial fertilization and egg incubation technique. In: J. Slembrouck, O. Komarudin, Maskur and M. Legendre (eds.). Technical Manual for Artificial Propagation of the Indonesian Catfish, Pangasius djambal. Karya Pratama. Jakarta, p. 73-93.

Slembrouck, J., Subagja, J., Day, D., \& Legendre, M. 2003 b. Induced breeding. In: J. Slembrouck, O. Komarudin, Maskur and M. Legendre (eds.). Technical Manual for Arti- ficial Propagation of the Indonesian Catfish, Pangasius djambal. Karya Pratama. Jakarta, p. 51-71.

Sudarto. 1999. Karakterisasi genetik dan zooteknik ikan lele (Clariidae) dan patin (Pangasiidae) dari wilayah Asia Tenggara. Makalah dalam: A. Hardjamulia, K. Sumantadinata, K. Sugama, A. Sudradjat dan E.S. Heruwati (eds.). Prosiding Seminar Hasil Penelitian Genetika Ikan, Jakarta, 8 Februari 1999, hlm. 26-29.

Suwarso \& Sadhotomo, B. 1995. Perkembangan kematangan gonad ikan selar bentong, Selar crumenopthalmus, (Carangiidae) di Laut Jawa. J. Pen. Perik. Indonesia, I(2): 3648.

Tahapari, E., Iswanto, B., Nurlaela, I., \& Sularto. 2010. Embriogenesis dan perkembangan morfologis larva patin nasutus, Pangasius nasutus Bleeker, 1863 (Pangasiidae, Siluriformes). Makalah dalam: A. Husni, Suadi dan I. Istiqomah (penyunting). Prosiding Seminar Nasional Tahunan VII Hasil Penelitian Perikanan dan Kelautan Tahun 2010. Yogyakarta, 24 Juli 2010, 9 hlm.

Xuan, L.N. \& Liem, P.T. 1998. Preliminary results on the induced spawning of two catfish species, Pangasius conchophilus and Pangasius sp 1 . in the Mekong Delta, Vietnam. In: M. Legendre and A. Parisele (eds.). The Biological Diversity and Aquaculture of Clariid and Pangasiid Catfishes in SouthEast Asia. Proceeding of The Mid-Term Workshop of the Catfish Asia Project, 1 1-15 May 1998. Cantho-Vietnam, p. 103-106. 